\title{
Investigation of Changes Implemented into Teaching Modern History
}

\author{
in Poland \\ Krystyna Teresa Nowak-Fabrykowski \\ Department of Teacher Education and Professional Development \\ Central Michigan University, USA \\ E-mail: nowak1k@cmich.edu ork.nowakfabrykowski@gmail.com
}

\author{
Eleonora Trzcinska \\ Didactics of history \\ University of Lodz, Poland \\ E-mail: dydaktykahistorii@gmail.com
}

\begin{abstract}
The purpose of this article is to analyze teaching of modern history in Poland and the teachers' role in the process of democratization. Forty-eight high school history teachers responded to a questionnaire investigating the curricula, textbooks, supplemental teaching materials and methods of teaching. The results demonstrate that since 1989 these instructors have had many more choices of textbooks compared to the past when just one government-recommended text was available. The teachers claim that textbook material is now more objective and does not contain "white spots." Teachers also admit they now can teach in more interactive ways using discussion and critical thinking, and present different points of view.
\end{abstract}

Keywords: Teaching of modern history, Poland, Teaching materials and methods of teaching

\section{Introduction}

History plays an important role in the education of a society; therefore, the teaching of contemporary history in schools merits investigation. What interests should schools serve? What values should be taught? According to Augigier (1999), the mission of schools is the transmission of cultures shared by society. School contributes to the life of society because it develops different competencies of citizenship. During a transition to a new political system, such as that experienced in Poland, education should help prepare young people for the new reality. The data on Scale of Approval of transition by the young people indicates that Poland has the heights approval of changes after 1990 and the most positive of all other Eastern European countries. (Zaleskiene, 2006)

The image of Poland is often wrong portrayed by the textbook of Eastern Civilization. Kulczynski's (2005) survey of textbooks using Poland as a test case has shown that: What references there are to Poland are often misleading or inaccurate and certainly incomplete. None of the textbooks provide a sustained narrative of Polish history, none attempt to connect the infrequent and miniscule dots they allot to Polish history. (p.170)

In many European counties qualities insurance as the process of evaluation provides hope that the material taught and the methods of teaching are accurate. As Rozsnyais (2003) stated: The Czech Republic, Hungary and Poland all have internal quality assurance systems in their institutions. They are mandated by law in the first two countries, whilst Polish institutions have taken the initiative to implement evaluation. To what degree can quality assurance contribute to promoting a better society 'to benefit from the richness of the European Higher Education Area including its democratic values, diversity of cultures and languages and the diversity of the higher education systems' (Prague, 2001) is a difficult question to answer.( p.278)

However some Polish teachers that are teaching in the USA are bringing relevant, plausible material and teach in the interactive way using maps and photographs of Poland then and now. (Sugarman-Banaszak, 2008)

Polish researchers see the problems of their country's transition into democracy with a different focus. For Konopka (1996), the most important factor following the collapse of the communist regime is to provide researchers the opportunity to study changing educational programs and implementing new textbooks. For Chelminska (1991), the most significant change is in Poland's culture, while Konopka (1996) believes previous research emphasized curriculum problems as the most significant factor creating most of the problems for teachers and students. Skowronek and Skowronek (1994), however, observe the same pre-1989 problems in the teaching of history still exist. 
In 1992, the Polish Ministry of Education emphasized developing the spirit of democracy for the new generation. This emphasis included patriotism, tolerance and societal participation. Considering the implications of ethical teaching, however, it is unclear whether Poland's schools are now truly free of indoctrination and censorship. With $21^{\text {st }}$-century global uncertainty, concerns about what we teach our children remain.

In 1994 Centkowski remarked that there are still problems in development of an historical consciousness in young people in Poland. Skowronek and Skowronek (1994) underline that while we can observe positive changes there are still many problems. Konopka (1996), for example, affirms that changes introduced in the curriculum and textbooks, along with an increased number of supplemental books, did not eliminated difficulties in teaching history. Contrarily, though, Vulliamy and Webb (1996) conducted research in Poland and affirmed the biggest changes seemed to occur in the teaching of history. They observed that teaching of history transformed from doctrinarian to the development of a new historical consciousness. However, other researchers such as Centkowski (1994) and Serwanski (1993) stress still-existing problem in the curriculum and in the content of textbooks. Serwanski believes new textbooks are largely the same as the old ones, the changes made are superficial. Konopka (1996) proposes the examination of new history textbooks to determine their merit and potential methodological problems.

This research attempts to answer four questions. The guiding question is what role history teachers' play in the process of Poland's democratization? The sub questions are :what methods of teaching are used now compared to that used prior to 1989 ,current textbooks; and whether the new curriculum and textbooks provide opportunities for instructors to work in more interactive ways and to discuss different points of view, stimulate critical thinking

After the collapse of the communist regime in Poland in 1989, changes in the educational paradigm became necessary (Nowak-Fabrykowski and Tardiff (1999), Nowak-Fabrykowski and Sosonowski, 1995). One assumption is that a teacher's responsibility lies in the preparation of his or her students to live in a democratic society. This notion comes from the ideal that a teacher is an agent of change, one who brings changes, reflects new values, beliefs, and the freedom of speech. We could assume that the topics, textbooks and especially new classroom approaches uphold new ethical values. It is apparent that changes in teaching modern history must follow changes in politics and new ethics, but ways to develop new dispositions in students of history remains unexplored.

Majorek (1996) stresses that for too long history teaching was based only on memorization of facts. He proposes a new approach based on asking questions and discovering lies and prejudice to better evaluate differences in lectures delivered by the same professors who taught during the socialist era.

The first question asked relates to the term "democracy" and its definition, but authors such as Benhabib (1996) and Young (2000) propose a different concept. According to Benhabib (1996) democracy called "deliberative" provides the possibility for a free discussion on topics that are of interest to everyone. Young's (2000) "communicative democracy" examines many perspectives, styles of conversation and expression. Print, Ornstrom and Skovgaard (2002) described two conceptions of democracy, the first of which relates to the function of government and the second examines philosophical questions related to the way of living. The second notion is linked with compromise and tolerance, listening to and accepting the opinions of others.

\section{Rationale}

According to Albala-Bernhard (1995), Polish society is weaker after the fall of communism, but reforms will help overcome those weaknesses. Researching the role of history teachers in preparing young generation for the new democratic society is important. The necessity of this type of research had been stressed in 1994 in Geneva on the conference organized by the United Nations Educational, Scientific and Cultural Organization (UNESCO). The aim of this conference was to examine teachers' roles in preparation for the new generation for peace, civil rights and democracy.

Furthermore, Perrot (1984) stresses that the mission of history teachers is to provide political instruction for future citizens. This mission could be accomplished if the teachers could show their students that the discussion of political problems is possible (Print et al, 2002). If a deliberative model of democracy were to be introduced in Poland every citizen would have the opportunity to initiate dialogue, ask questions, present arguments and provide reflective thought.

\section{Attitudes toward changes of students, parents and teachers}

Slomczynska and Shobad (1995) believe generational differences cause differences of opinion. Students, parents and teachers all have different attitudes about the changes implemented in Poland. Students primarily support changes, especially in the area of ideology of democratic capitalism, an ideology valued by the political elite and "mass media." Adolescents, however, have limited experience with communistic values; while adolescents have the greatest possibility to learn, they lack the ability to accurately evaluate the new political and economical order. Because of this, young people could be less favorable for systemic changes that can cause instability and economical insecurity. 
Slomczynska and Shobad (1995) suggest more teachers than parents likely would favor systematical changes because civil education requires an adequate understanding of democracy and economy. Young (2000) emphasize that free, active and diverse civil society are most important for democracy, but Poland is a traditional country and remains quite homogeneous. Vullaiamy G., and Webb, R. (1996) noticed during their interviews with students at the Lyceum in Lodz that students believe history in Poland does not have anymore "white spots" and that teachers can say the truth.

Chelminska (1991) believes discussions on the creation of democracy in Poland are linked to power and the people's right for freedom. She deems the level of political culture and knowledge is necessary to bring Poland to its new democratic stage. The necessary factor in the development of democracy, she writes, exists in one's capacity to criticize reality, but criticism by everyone - not just the elite. Uryga (1991) shares this conviction stressing that democracy refers to the culture of people through the way they live, their contacts with others, each person's place in the group, and a collective cooperation in the establishment of laws and obligation. Democratic culture should be taught in school and teachers play very important roles to accomplish this objective.

\section{Analysis of the Ministry of Education Journal 1989-1996 and the program of contemporary history (1957-1990)}

The Journal of the Ministry of Education shows that only one textbook for teaching contemporary history (Siergejczyk) was recommended until 1999, but since 1994 many other textbooks were suggested. Since 1990 several supplementary readings were also suggested. It should be noted that every year there are many more textbooks on the market and can be accepted by the history teachers.

If we look at the curricula published between 1957 and 1990 we notice that they stress the changes that occurred since 1980. In 1957 the program underlined the role of Soviet Union in the creation of democracy for people, Lenin's socialistic model, and the universal cooperation between socialistic countries. Furthermore the singular program described two major forces that dominated the world: socialism and capitalism. It also names obligations of the socialistic citizens.

In 1959, the program helped socialistic countries in economical, sociopolitical and agricultural ways by explaining the importance of fighting to establish the "power of people." In 1996, the program demanded historical knowledge of the politics related to "the Cold War," as well as the Soviet Union's role in creating world peace. Other suggested topics include the importance of the power given to people, economic transformation, the socio-political climate of 1947-49, but more predominant is the danger of the Third War and the atmosphere of political terror imposed by the capitalist countries.

The programs of 1970 emphasized the role of the Soviet Union in building a socialistic Poland. Changes in the programs were observable since 1981 and new themes included an analysis of the different models of democracies. The goals to eliminate political opposition and the fight to defend communism remained. In 1986 genuinely observable changes manifested when teachers encouraged discussions about 1981's "martial law" and changes in the international politics. Topics such as Soviet aggression on Poland in 1939 and the Katyn massacre of 1944 were previously forbidden, but in 1990 relaxed liberties in educational programs allowed for the discussion of the crisis in 1968, the workers' protest in Gdansk in 1981, and the error of the communistic system.

\section{What are the roles of history teachers? What changes have been implemented?}

According to Dorion (1984), the scientific, ideological and pedagogical content of textbooks depends on the orientation of the educational system in which they are written. Therefore, according this approach, "the textbook is not only work of an author, his/her competence, but also reflecting society and serves transmission of ideology, values, attitudes accepted in the socio-economical and ideological context" (p.8).

Analyzing theoretical problems related to modernization, Maternicki (1996) describes textbooks published between 1948 and 1956 as a source of sorrow since they were the sources of Poland's communist indoctrination. Some of these textbooks used by Polish instructors were nothing more than translated Soviet textbooks.

A return to the truth became possible after 1980 following the Solidarity movement, the government's first official opposition. Maternicki (1993) stresses that "according to the list of the Ministry of Education now professors have many choices of textbooks" (p.63). But what textbooks are they using and what reasons lay behind their choices?

\section{Methodology}

The basic methods behind this research are qualitative based on the collection of questionnaire data and descriptive analyses. This research attempts to answer four questions: namely what role history teachers' play in the process of Poland's democratization, what methods of teaching are used now compared to that used prior to 1989; what are qualities of current textbooks and whether the new curricula and textbooks provide opportunities for instructors to work in more interactive ways giving an opportunity to discuss different points of view and stimulate students' critical thinking. 


\section{Population}

Sixty high school modern history teachers working in one of the four provinces in the Lodz region (lodzkie, skierniewickie, piotrkowskie, sieradzkie), collaborating as cooperating teachers with the Department of Didactique of History at the University of Lodz in Poland.

\section{Results}

Forty-eight modern history teachers replied to the questionnaire (80\%) (Annex 1). Most of them taught for the last four years and the majority (79\%) for ten years. The shortest length of employment was three years and seven months and the longest teaching experience was thirty-seven years.

The teachers report familiarity with four different textbooks available for the teaching of modern history None of the instructors uses just one. Among the most popular is a text by Radziwil and Roszkowski (2001) - 75\% teachers stated this textbook is the best because it is the most objective, it encourages students to think, it is very well written and it could be adapted to the existing program. The textbook also features notes, illustrations and original text and provides choices of material that could be used, making possible fair evaluation and allowing different interpretation of the facts. Another textbook, written by Pankowicz (1991) - 53 \%, also received good evaluations from teachers who believe the book provides easy access to information for which students are looking, claiming "it is correct without ideology that was typical before 1989." The teachers evaluate this textbook as the most objective. One teacher claimed that this textbook is "the most liked by the students." In third position a textbook by Tusiewicz (1993)- 42\%, which, according to teachers, "is easy to understand, gives good details and has good original text." Next is a textbook by Probis(2003)-16\%, which is commended for "presenting the most recent facts."

Insert Figure 1 Here.

According to the teachers textbooks underwent changes on several different dates. These dates depend on the places where the schools were located and the schools themselves, but it is clear that many changes occurred when political changes became evident. One teacher who taught for the last 34 years provided the following dates: 1963, 1975, 1982, $1987,1989,1990$, and 1991. Others think the most important were changes in the program and textbooks in 1993, 1994 and 1995, but are these changes mostly didactical or historical?

\section{Insert Figure 2 Here}

For nine teachers $(19 \%)$, changes are didactical and for twenty-five, $(52 \%)$ the changes are historical. For fourteen $(29 \%)$, the criteria for changing textbooks were a combination of both.

\section{Methods of teaching}

Did the methods of teaching change with the textbooks? For this question there are no clear or unanimous answers. Insert Table 3 Here

Fifteen teachers (31\%) agreed that they changed methods of teaching when they changed textbooks, but seventeen (35\%) disagreed that changes of textbooks was related to their changes of teaching, and ten teachers $(20 \%)$ were undecided. Many of the instructors stated it was not the textbook changes, but instead years of teaching experience ultimately helped them to change their methods of teaching (14\%). Some said they changed their methods of teaching based upon the competence of their students, while some thought the additional books used helped them become better.

All of the instructors agreed current methods such as discovery and problem solving, called "active methods," replaced the older "passive methods." The new teachers stressed they did not change their methods of teaching because they started in the new system when active methods of teaching were required.

\section{Limitations}

This research is limited to one city and does not demonstrate similar conditions across the country. The sample is small and limited to teachers of contemporary history. Ongoing research obviously is necessary to follow up with the changes. For Print et al. (2002), teaching democracy is based on the dialogue between the teachers and the students, and parents should also be included in this important discussion to determine whether schools in Poland still impose values and beliefs, or if schools are truly free of indoctrination and practice freedom of thoughts and ideas.

Do the teachers stimulate students so they are able to live and create a more democratic society? Is teaching more ethical than it was before? Do the teachers and students value freedom of thoughts and beliefs and dialectic reasoning? Student interviews or a questionnaire designed specifically for students would provide more information and give a voice to the students as well as the teachers.

\section{Conclusion}

According to Konopka (1996), the negative elements of teaching modern history in Poland were primarily with the textbooks used and the methods of teaching. The textbooks contained many "white spots" and rigid curricula made 
impossible discussions and limited freedom of thoughts by reinforcing reproduction, memorization, indoctrination and censorship. Ethical teaching was impossible.

There are many indicators revealing occurrences of change in the teaching of modern history in Poland. Some of these changes relate to the methods of teaching and the textbooks chosen by teachers for their respective curricula. One of the most fascinating elements was determining why teachers made their choices when looking for new textbooks. Many instructors referred to "the objective text without ideology," textbooks which offer the possibility of discussion and interpretation and encourage students to think. Instructors also take into consideration which textbooks are liked by their students.

In Poland the majority of people believe that the new system gives liberty of thoughts and expression (Stepan and Linz, 1998, p.208). It is a sign that the majority values the process of democratization. The same results were obtained by Mishler and Rose (1999) in 1991 when investigating if there was support for the new system in post-communistic countries (p.84).

While this analysis provides limited demonstrated changes, most notably perhaps is the existence of several new sources for teaching, valid reasons behind textbook selection and takes into consideration students' opinions as future indicators, since providing students the freedom to discuss and interpret facts is crucial to develop their understanding of true democracy. To determine whether teachers impose their values, attitudes and norms, it is necessary to interview students and their parents.

This research clearly cannot answer fully these questions, but it demonstrates progress toward democracy and ethical teaching.

\section{References}

Albala-Bertrand, L. (1995). L'éducation à la citoyenneté. Information et innovation en éducation. Bureau International d'Éducation, Genève.

Augigier, F. (1999). School disciplines, social representations, and the construction of the didactics of history, geography, and civics. Instructional Science, (27), 97-117

Benhabib, S. (1996).Democracy and difference :Contesting the Boundaries of the Ppolitical. N.J.: Princeton University Press.

Centkowski, J. (1994). Poland, Historical Culture -Historical Communication. International Bibliography. Frankfurt: 295-305.

Chelminska, M. (1991). Ksztaltowanie demokracji kulturalnej w koncepcjach Rady Europy. (Creation of cultural democracy in the Conception of European Council)Dans Pluta, J., Stawowy E., Wikanowicz,S. Demokracja dla wszystkich, Krakow: Znak.

Dorion, C. (1984). Grille d'analyse pour les manuels scolaires de scienceshumaines. Thèse de maîtrise. Université Laval, Sainte Foy, Québec.

Konopka M. dans Kujawska (1996) Nauczyciel historii. Ku nowej formacji dydaktycznej. (History Teacher. Towards New Formation). Poznan: Instytut Historii UAM.

Kulczynski, J. (2005). Eastern Europe in western civilization textbooks: The example of Poland. The History Teacher, 38(2), 153-177

Majorek, Cz. (1996).Wizerunek nauczyciela historii. Wspolczenosc w perspektywie historycznej.(Image of the History Teacher. Modern Aspect in the Historical Perspective). In Kujawska.M.(1996) Histori Teacher Towards New Formation. New Nauczyciel historii. Ku nowej formacji dydaktycznej.(Poznan: Instytut Historii UAM.

Maternicki, J.(1996). Perspektywiczny model nauczyciela historii. In Kujawska,M(Ed.). Nauczyciel historii. Ku nowej formacji dydaktycznej. Poznan: Instytut Historii UAM.

Mishler, W., \& Rose, R. (1999). Five years after the fall: Trajectories of support for democracy in post-communist Europe. Dans Noris, P. Critical citizens. Global support for democaratic governance. New York: Oxford University Press. implemented in the History Teachers' Education Programs. Teaching and Teacher Education, 15, 829-834.

Nowak-Fabrykowski, K., and Tardif,M ( 1999). "The changes that were postulated and implemented in the History Teachers' Education Program in Poland after the collapse of the communist's regime. "Teaching and Teacher Education, 15, $829-834$.

Nowak-Fabrykowski, K., \& Sosnowski, A.(1995) Education in Transition: Changes in the Polish School System.” Canadian and International Education, (with A. Sosnowski.), 24(2), 55-64.

Pankowicz A.(1991).Historia Polski i swiat wspolczesny. Polish History and History of the World. Warszawa: Wydawnictwo Szkolne i Pedagogiczne. 
Perrot, M. (1984). Les finalités de l'enseignement de l'histoire. Colloque national sur l'histoire et son enseignement. Paris CNDP, 38-39.

Print, M, Ornstrom, S. \& Skovgaard N. H. (2002). Education for democratic processes in schools and classrooms. European Journal of Education, 37(2), 193-210.

Pronobis, W. (2003). Polska i swiat w XX wieku." (Poland and the World of XIX century). Warszawa: Spotkania.

Radziwill, A.\& Roszkowski,W. (2001). Historia od 1871 do 1945. and Historia od 1945 do 1990.( History from 1871 to 1945 and History from 1945 to 1990). Warszawa: PWN.

Rozsnyai, Ch. (2003). Quality assurance before and after 'Bologna' in the central and eastern region of the European higher education area with a focus on Hungary, the Czech Republic and Poland. European Journal of Education, 38(3), 271-284.

Serwanski, M. (1993). Enseigner l'histoire en Pologne aujourd'hui. Cahier de Clio, 115.

Skowronek, M., \& Skowronek, J. (1994). La Révolution française dans les manuels scolaires polonais actuels". Dans Riemenschneider R., Images d'une Révolution. La Révolution française dans les manuels scolaires d'histoire du monde. Paris: Schriftenreihe des Georg-Eckert-Instituts.

Slomczynski, K., \& et Shabad, G. (1995). Continuity and change in political socialization in Poland. Comparative Education Review, l4l(1), 44-70

Stepan, A., \& et Linz, A. (1998). Post-communist Europe: Comparative reflections. In Inoguchiu, T., Newman,E. \& Keane, J. The changing nature of democracy. New York: United Nations University Press.

Sugarman-Banaszak, C. (2008).Stepping into the past: using images to travel through time. Teaching History, 130, $24-29$.

Tusiewicz, R. (1993). Polska wspolczesna 1944-1989. ( Contemporary Poland 1944-1989).

Uryga Z. (1991). Wychowanie do demokracji. Dans Pluta, J., Stawow, E., Wikanowicz, S. Demokracja dla wszystkich, Krakow: Znak.

Vullaiamy G., \& Webb, R. (1996). Education during political transition in Poland. International Journal of Educational Development, 16(2), 111-123.

Young, I. M. (2000). Inclusion and democracy. New York: Oxford University Press

Zaleskiene, I. (2006). Attitudes of young people in Easter Europe and Central Europe towards social changes. Pedagogy Studies 81, 96-100.

Annex 1

Questionnaires

Name of School nom de

l'école

Years of Teaching

1. What textbook for teaching modern history are you using?

2. What textbook for teaching modern history have you been using in your teaching?

3. Do you remember dates for changing textbooks of modern history?

4. According to your opinion the changes of textbooks were influenced by didactical reasons or historiographical?

5. Did the methods of your teaching of modern history changed when you changed textbooks? Explain how.

6. Are you using additional materials?

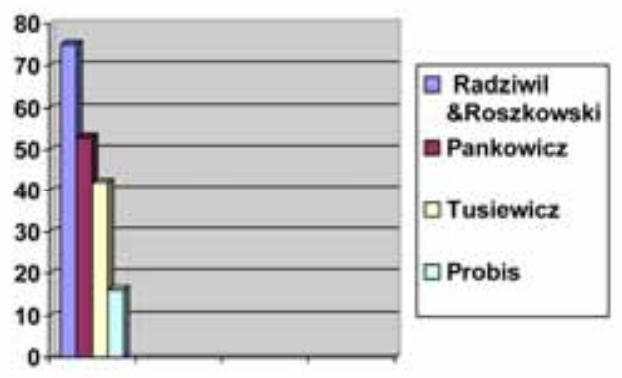

Figure1. The most popular modern history textbooks. 


\section{Changes in the Programs and Textbooks}

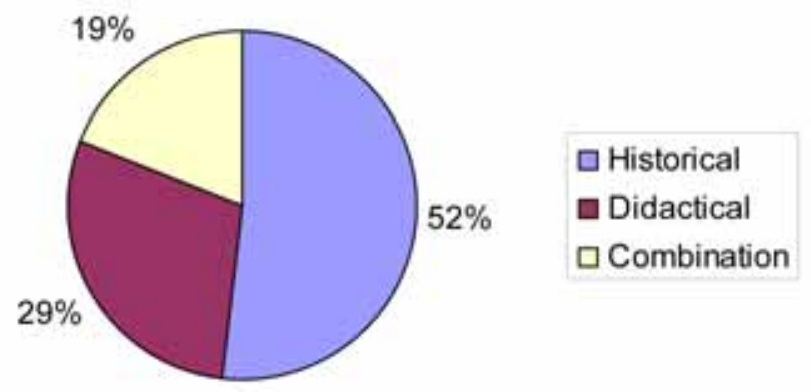

Figure2. Reasons for changes in programs (Curricula) and textbooks.

\section{Changes of Teaching Methods and Textbooks}
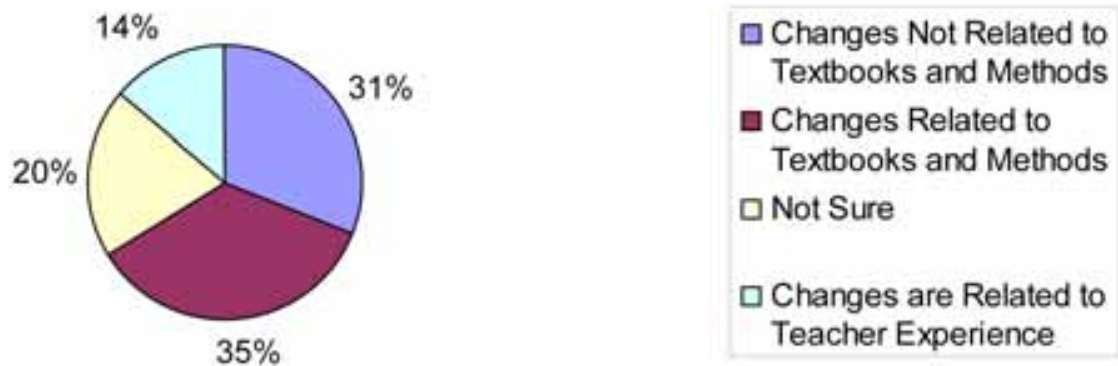

Figure 3. Are the changes in teaching methods related to new textbooks? 